\title{
Why Is the AfD so Successful in Eastern Germany? An Analysis of the Ideational Foundations of the AfD Vote in the 2017 Federal Election
}

\author{
Maria Pesthy $\cdot$ Matthias Mader $(\mathbb{D} \cdot$ Harald Schoen
}

Received: 9 April 2020 / Revised: 14 October 2020 / Accepted: 20 October 2020 / Published online: 24 November 2020

(C) The Author(s) 2020

\begin{abstract}
The Alternative for Germany party (AfD) has been more successful electorally in eastern than in western Germany. In this paper, we look at nativism coupled with populist attitudes as possible contributors to the 2017 federal electoral outcome. We compare two alternative mechanisms for the varying election results, the first being whether individuals living in eastern Germany are, on average, more nativist and populist inclined; the second, whether nativism and populism are more salient when these voters go to the polls. The results show that there indeed exists a slightly higher level of nativist and populist sentiment among the east German citizens than among the west Germans. This difference concerns older east Germans in particular, who were politically socialised during the German separation. Furthermore, elements of nativist and populist ideas explain electoral support for the AfD in both parts of the country, but nativism appears to be more relevant in the east. Overall, the analysis of the short-term campaign panel data from the German Longitudinal Election Study suggests that the inspected ideational foundations contribute to the east-west gap in AfD support without accounting for it completely.
\end{abstract}

Keywords AfD vote $\cdot$ Populism $\cdot$ Nativism $\cdot$ East-west differences

Electronic supplementary material The online version of this article (https://doi.org/10.1007/ s11615-020-00285-9) contains supplementary material, which is available to authorized users.

\footnotetext{
M. Pesthy $\cdot$ H. Schoen

School of Social Sciences, University of Mannheim, Mannheim, Germany

M. Mader $(\triangle)$

Department of Politics and Public Administration, University of Konstanz, P.O. Box 90, 78457 Konstanz, Germany

E-Mail: matthias.mader@uni-konstanz.de
} 


\section{Warum ist die AfD in Ostdeutschland so erfolgreich? Eine Analyse der ideellen Grundlagen der AfD-Wahl bei der Bundestagswahl 2017}

Zusammenfassung Die Alternative für Deutschland (AfD) war bei Wahlen in Ostdeutschland erfolgreicher als in Westdeutschland. In diesem Beitrag betrachten wir Nativismus gepaart mit populistischen Einstellungen als Faktoren, die möglicherweise zu den besagten Wahlergebnissen beigetragen haben. Es werden zwei alternative Erklärungsmechanismen für die variierenden Wahlergebnisse verglichen: erstens, ob Ostdeutsche im Durchschnitt eher zu Nativismus und Populismus neigen; zweitens, ob Nativismus und Populismus bei ostdeutschen Wählern einen größeren Einfluss auf das Wahlverhalten haben. Die Ergebnisse zeigen, dass es tatsächlich ein leicht höheres Niveau nativistischer und populistischer Einstellungen unter den ostdeutschen Bürgern gibt als unter den westdeutschen. Dieser Unterschied betrifft vor allem ältere Ostdeutsche, deren politische Sozialisation während der deutschen Teilung stattfand. Des Weiteren erklären nativistische und populistische Einstellungsmuster die Wahlunterstützung für die AfD in beiden Teilen des Landes, aber Nativismus scheint im Osten relevanter zu sein. Insgesamt legt die Analyse der Daten des Wahlkampfpanels der German Longitudinal Election Study nahe, dass die untersuchten ideellen Grundlagen zum Ost-West-Unterschied in der AfD-Unterstützung beitragen, ohne diesen jedoch vollständig abzubilden.

Schlüsselwörter AfD-Wahl · Populismus · Nativismus · Ost-West-Unterschiede

\section{Introduction}

The most recent significant newcomer to the German party system, the Alternative for Germany party (AfD), has been considerably more successful at the polls in eastern Germany than in western Germany. In the latest federal election (2017), the party received $11 \%$ of the popular vote in western Germany versus $22 \%$ in the east (Der Bundeswahlleiter 2018). To account for this difference in electoral support of a party with questionable democratic qualities, a straightforward and widely used approach refers to a regional gap in society that might be considered worrisome in terms of social cohesion. Following this line of reasoning - and resembling earlier research on regional differences for right-wing extremist parties and Die Linke-previous research argued that differences in electoral support for the AfD reflect differences in the prevalence of factors that fuel or limit such support. For example, the existence of long-term regional networks in eastern Germany is considered a factor benefiting AfD support (Goerres et al. 2018). Likewise, differences in the prevalence of anti-immigration attitudes are considered a driving force behind the gap in electoral support of the AfD (Arzheimer n.d.; forthcoming).

Although it is plausible to assume that differences in electoral support reflect differences in the prevalence of factors relevant for voting behaviour, prior research emphasised that the distribution of party support may not simply mirror differences in society. Rather, social and economic characteristics and sociopolitical attitudes may also differ in their impact on vote choice. Given the set of viable parties, people 
might vote for the AfD to different degrees despite being similarly attitudinally predisposed to do so. The possibility of regional variation in the impact of facilitating factors of AfD support suggests that the process of electoral decision making itself (and not just the inputs to the process) makes a difference. Furthermore, it cautions against the backward reasoning that a regional gap in AfD support necessarily indicates differences in the prevalence of factors facilitating the AfD vote.

This differentiation applies to the attitudinal facilitators of voting for the AfD that can be linked to its key ideational features. The AfD is widely considered to be the German incarnation of a type of right-wing populist party, especially since its recent transformation in the context of the European refugee crisis (Arzheimer and Berning 2019; Goerres et al. 2018; Decker 2016). These parties may attract voters by their populism—a "thin" ideology—as well as by their right-wing policy stance, which primarily rests on the idea of nativism—a "thick" ideology (e.g., Betz 2017a; Decker 2018; Mudde and Rovira Kaltwasser 2017). Accordingly, populist and nativist attitudes may drive citizens' vote choices for the AfD and hence make the AfD a right-wing populist party when voter motives are considered. Provided the roles of populist and nativist attitudes in eastern and western Germany are the same, the differences in electoral support for the AfD may reflect similar differences in populist and nativist attitudes. However, this distributional assumption cannot be taken for granted. From more widespread demonstrations and violence against refugees to a more radical appearance of the AfD in eastern Germany, contextual differences suggest that populism and nativism could be psychologically more salient in eastern Germans' minds when they go to the polls. Furthermore, we cannot rule out that the weights of populist and nativist attitudes differ in such a way that in one region "thin" populism trumps "thick" nativism, whereas in the other region the opposite applies. Such a pattern would run counter to the above-mentioned mirror hypothesis, and it would demonstrate that the attitudinal ingredients of the AfD work in complex ways and are subject to regional differences.

To this end, we studied the role of nativism and populism in affecting vote choice for the AfD in eastern and western Germany in the 2017 federal election. Our study enables us to assess the relative importance of the two core ideological dimensions at the individual level. Even though current research on the topic often refers to Mudde (2007) and his identification of populism and nativism as the constitutive ideological features of many new far-right parties, we are not aware of voting research that accounts for these two concepts simultaneously, using measures explicitly designed to capture them. We contribute to closing this research gap by drawing on the comprehensive measures of populist and nativist attitudes available in the campaign panel survey of the German Longitudinal Election Study (GLES). Doing so allows us to study the relative strengths of association between populism, nativism, and AfD vote choice in the 2017 federal election. We are thus in a position to examine whether the thick or the thin ideational features are more important in the AfD vote. Building on this set-up, we evaluate the prevalence of populist and nativist attitudes as well as their association with the AfD vote in eastern and western Germany. This allows us to examine regional differences in the distribution and behavioural implications of the main ideational motivations of the right-wing populist vote. 
Analysing time-series panel data, we find that individuals living in eastern Germany, older people in particular, are somewhat more populist and nativist than those living in western Germany. Second, populist and nativist sentiments increase the likelihood of an AfD vote in both parts of the country. Both in eastern and western Germany, nativism is more closely associated with the AfD vote than populism is. Accordingly, the "thick," substantive nativist thoughts are more important than the "thin" populist ones. This particularly applies in the east. By and large, the data analysis suggests that the ideational foundations contribute to the east-west gap in AfD support without accounting for it completely.

The paper is structured as follows: In the next section, we discuss the general model of electoral behaviour we apply, as well as two specific pathways through which nativist and populist attitudes can be related to AfD-support in eastern and western Germany. In the third section, we discuss the data and specific operationalisations we employ. In the fourth section, we present descriptive and multivariate results from our empirical analyses. The final section concludes the paper and discusses limitations as well as possible avenues for future research.

\section{Relevant Literature and Theoretical Foundations}

Because our interest lies in the analysis of two specific ideational foundations related to variable electoral support of the AfD via two potential pathways, we employ this section of the paper to present previous research immediately relevant to our own. This includes a description of important characteristics of the AfD, the definition of nativist and populist attitudes we adhere to, the relevance of looking at these attitudes in combination as well as the model of electoral choice we integrate these idea elements into. Based on this model, we deduct two potential mechanisms through which the same idea elements can possibly explain differing electoral support.

Populism and nativism are currently widely discussed as the most relevant programmatic features of the new breed of right-wing parties that have established themselves throughout Europe in the recent past (Betz 2017a; Mudde and Rovira Kaltwasser 2017). The AfD is generally considered to be the German incarnation of this party type, especially since its latest evolvement in the context of the European refugee crisis (Arzheimer and Berning 2019; Bieber et al. 2018; Decker 2016). Accordingly, the AfD currently enjoys a unique position in the German party system with regard to the ideational features of populism and nativism. Some populist ideas can be found within The Left (Jesse 2017; Olsen 2018), but the AfD clearly is the German party with the most consistent populist narrative. Furthermore, the AfD currently is the only German party in the federal parliament with a clear nativist program. While traditionally the Christian Democratic Union/Christian Social Union (CDU/CSU) have also offered ethnonational and anti-immigration positions, these have been much more moderate than the AfD's, especially during the current chancellorship of Angela Merkel (Martin 2019). By implication, the AfD is the only party combining nativism and populism into a consistent populist radicalright program (Decker 2018). Nativism and populism therefore appear to provide 
a promising starting point for our analysis, even though other features may be worth examining as well.

The analysis of the relevance of populist and nativist attitudes in electoral choice may not only illuminate east-west differences in AfD electoral success but also fill a gap in current research on the right-wing populist vote more generally. As Betz (2017b) points out, the exact nature of the relationship between nativist and populist attitudes has not yet been sufficiently analysed, with a particularly important gap still existing in our lack of knowledge concerning the importance of nativism in explaining populist mobilisation. The author presents a convincing case, anchored in developments reaching back as far as the 19th century and arguing that Brexit and Trump's election as well as the success of the AfD are, in large part, due to "successful radical right-wing populist mobilization" (p. 183). Betz furthermore points towards the naturally existing overlap between populism and nativism, given that ingroup-outgroup demarcation plays a defining role for both ideologies. Other authors who also work on disentangling populist and nativist idea elements (e.g., Kešić and Duyvendak 2019) restrict their analyses to the political discourse on the elite level, while Caramani and Manucci (2019) define a "thick" version of populism as a combination of populist and nativist/xenophobic narratives to classify parties along those lines (see also Bowles 2020, Otjes et al. 2018, Riedel 2018, and Rooduijn and Akkerman 2017, among others, for further current meta-level and conceptual work).

Even though nativism and populism have played a significant role in political science research on the level of party systems, analyses looking specifically at voter attitudes are still few and far between. This situation is probably caused at least in part by the fact that populism as a concept has been a highly debated and controversial issue. Furthermore, the question of whether populist attitudes exist on the micro level has only recently, and in conjunction with the ideational approach to populism, been answered to some degree at all (Hawkins and Rovira Kaltwasser 2017). Pioneering studies with regard to micro-level measures of populism have been published by Hawkins et al. (2012) and Akkerman et al. (2014), as well as Castanho Silva et al. (2018) and Schulz et al. (2018). Although the work presented in these studies advances our understanding of populist idea elements on the voter level, it rarely connects these idea elements with nativism, a combination necessary for painting the whole picture with regard to explaining electoral support for farright populist parties (notable exceptions using individual-level data on both populist and nativist attitudes are Blanchet and Medeiros (2019), with their study of electoral support for the secessionist Parti Québécois, and Rooduijn (2014), with his analysis of Freedom Party voters). Hence, while the main focus of this contribution is on the east-west differences in AfD success, the simultaneous accounting of populist and nativist attitudes promises more direct answers to the more general question of the relative importance of these two factors for the right-wing populist vote than were previously available.

We follow Mudde $(2004,2007)$ in understanding populism as a thin ideology "that considers society to be ultimately separated into two homogeneous and antagonistic groups, the 'pure people' versus the 'corrupt elite"' (Mudde 2004, p. 543). A closer look at this differentiation shows that it entails two distinct propositions: one 
concerning anti-elite sentiment and the other concerning the perceived similarity of all members of the people. Furthermore, according to this definition, populism also encompasses the idea that "politics should be an expression of the volonté générale (general will) of the people" (Mudde 2004, p. 543). These three dimensions of populism jointly constitute populist attitudes or populist politics. Importantly, populism understood in this way can also be found on the left side of the political left-right divide, and it frequently has been, especially in Latin American countries (Mudde and Rovira Kaltwasser 2017) as well as in Greece and Spain.

To grasp the ideational elements that add right-wing substance to the thin ideology of populism, we again rely on Mudde and use his conception of nativism. Nativism claims that (all) people living in a country should be part of the native group, and that "non-native elements [...] are fundamentally threatening to the homogenous nation-state" (Mudde 2007, p. 19). The definition implies a conceptualisation of the "true" people as members of an ethnoculturally defined nation on the one hand and a negative attitude towards anyone (and anything) foreign on the other hand. In short, nativism is a combination of two distinct features, ethnonationalism and xenophobia.

So how do populism and nativism influence individual vote choice? We keep the model as simple as possible. At the core of most theories of vote choice is the idea that citizens will choose the party that they feel best represents their values, general attitudes, and specific views on issues they care about (Campbell 1980 [1960]; Downs 1957; Rabinowitz and Macdonald 1989). Applied to nativism and populism, this means that citizens may compare their own attitudes regarding these idea elements with the corresponding stances of the political parties and then develop a preference for the party that fits best with their own attitudes. ${ }^{1}$ Because the AfD has, in comparison to the other parties in the German party system, the most explicitly populist and nativist program, the model suggests that citizens with populist attitudes will find the AfD attractive, as will citizens with nativist orientations. Indeed, previous research has presented evidence along these lines (Klein et al. 2018; Schmitt-Beck et al. 2017; Steiner and Landwehr 2018; Pappi et al. 2019). Furthermore, following Klein et al. (2018), who point to previous research on the success of more traditional right-wing parties in Germany in the $1990 \mathrm{~s},{ }^{2}$ AfD support might be particularly strong among citizens who exhibit both high levels of populism and high levels of nativism and may thus be particularly attracted to the party that offers this particular combination of ideational features (see also Schwarzbözl and Fatke 2016).

The core of the present analysis is our look at two mechanisms through which the difference in electoral support for the AfD in eastern and western Germany might

\footnotetext{
1 We consider populist and nativist attitudes to be stable mental representations centrally located in citizens' belief systems, and hence, like value orientations, are located at the beginning of the "funnel of causality" in the process of electoral decision making.

2 Accordingly, the interim electoral success of traditional right-wing parties such as Republikaner (REP) and Deutsche Volksunion (DVU) was the result of a particular combination of chronic frustration with politics and extreme right-wing orientations (e.g., Arzheimer et al. 2001; Klein and Falter 1996) at the individual level, combined with suitable opportunity structures that allowed these right-wing parties to make these attitude combinations salient (Arzheimer and Carter 2006).
} 
come about. The first mechanism concerns the prevalence of populist and nativist orientations in the heads of citizens inhabiting the two different regions of Germany. There are several reasons to expect that differences could be present. Against the backdrop of different socialisation experiences made before reunification and continuing differences in living conditions, attitudinal variation between the two parts of the country certainly seem possible. Those of the following considerations that point to the implications of different socialisation experiences made before unification of course imply that east-west differences should be particularly pronounced among older Germans, i.e., those who made these different experiences firsthand. ${ }^{3}$ Therefore, we will distinguish between these age groups in the descriptive part of the empirical analysis below. On the other hand, we also know from socialisation research that parents are among the most important socialisation agents and transmit many of their own views to their children (Sears and Brown 2013). We can thus assume that these considerations - in addition to those regarding differences in current living conditions-have implications for the younger generations as well.

Regarding populism, socialist ideology in the former German Democratic Republic (GDR) portrayed "the people" as a homogenous group of proletarians, while representation and pluralism were not part of the socialist understanding of democracy (Dalton 1994). Furthermore, the revolutionary struggle against the authoritarian SED (East German Communist Party) regime created a stark ingroup-outgroup distinction between "the people" and the political elites, which was epitomised in the slogan "Wir sind das Volk" ("We are the people") that became the battle cry for freedom in the 1989 peaceful revolution. These ideological views might have shaped (older) East Germans' notions about popular sovereignty and their beliefs about the homogeneity of the people, leading to differences with the (older) West Germans, who were socialised in a liberal representative democracy. As far as the element of elite criticism in the concept of populism is concerned, inequalities in living conditions (Statistische Ämter des Bundes und der Länder 2015) and the underrepresentation of east Germans among political elites (Träger 2017) may drive subgroup differences that are not limited to the older segment of the population.

As for nativism, in the GDR the traditional notion of Germany as an ethnic nation was not explicitly juxtaposed-or augmented-with the civic ideas of constitutional patriotism that became a mainstream conception of national identity in West Germany (Kronenberg 2013; Poutrus et al. 2000). The disregard for alternative conceptions of national identity might have given room to the traditional notion of a community of descent to live on. ${ }^{4}$ Furthermore, migrant density was and is much lower in the east than in the west (Statistisches Bundesamt 2018). In the absence

\footnotetext{
${ }^{3}$ From a strict primacy socialisation perspective, there should be no difference between Germans in the two parts of the country who experienced their formative years before the German division. Not allowing for any socialisation throughout the life cycle, however, would surely be an overstatement of primacy principle (e.g., Searing et al. 1976). Unfortunately, there are very few members of these cohorts alive today, preventing us from exploring this question empirically.

${ }^{4}$ However, the official ideological education tried to instil antifascism in GDR citizens, which, if successful, might have immunised older east Germans in particular against the allure of a party whose members partly toy with Nazi parlance and practice historical revisionism. Research indicates, however, that these attempts have had limited success (e.g., Schubarth and Schmidt 1992).
} 
of positive interpersonal contact, individuals living in eastern Germany typically exhibit increased perceptions of cultural threat emanating from increasing ethnic heterogeneity compared with their more experienced compatriots in western Germany (Pickel 2019; Wagner et al. 2003; see also Stecker and Debus 2019 for an application of this theory in the Bavarian context). This inexperience presumably interacts with the continuing economic disadvantages that low-skilled groups, especially, suffer in eastern Germany in comparison to similarly endowed west German counterparts. As a consequence, not only might immigration be seen as a larger economic threat in that part of the country, but anti-elitism might also be more widespread due to the continuing failure of the reigning governments to realise the long-promised alignment of living conditions in the two parts of the country.

The second mechanism with the potential to explain discrepancies in AfD support between east and west Germans concerns differences in the effects of populism and nativism on vote choice. Even if the levels of these ideational features are the same in both parts of the country, larger effects in the east-a greater relevance of these features when citizens decide how to vote-might also lead to more AfD support. It is a well-established insight of electoral research that the relevance of individual-level features is in large part a function of the communicative context in which individuals think and act (e.g., Campbell 1980 [1960]). Accordingly, differences in the relevance of populism and nativism for vote choice are a function of different communicative contexts in eastern and western Germany. Two features are presumably of particular importance: the overall volume of populist and nativist topics and the clarity of AfD electoral supply on these dimensions. To the extent that the political discourse in eastern Germany revolved more strongly around these features, and to the extent that the AfD is more visibly advertising populist and nativist stances in that part of the country, effects of nativism and populism at the individual level should be stronger there than in western Germany. While a systematic analysis is still pending, a number of different facts suggest that these east-west differences at the contextual level are indeed present. Demonstrations against the refugee policies and hate crimes against refugees were more widespread (Benček and Strasheim 2016) and thus likely to be noticeable in eastern Germans' daily lives and the regional media coverage. Furthermore, the regional organizations of the AfD in the east kept close ties to the Pegida (Patriotic Europeans Against the Islamisation of the West) demonstrations (Dostal 2015). By and large, the AfD's right-wing populism was more radical in the east than the west (Bieber et al. 2018, p. 441; Jesse 2017, p. 47). This has subsequently led to severe internal conflicts, up to a recent proposal of an east-west split of the party, similar to the division of labour practiced by the CSU and CDU in Bavaria and the rest of the country.

Summing up, we follow Mudde and Rovira Kaltwasser's work in defining populist and nativist party positions and attitudes. Integrating these attitudes into a simple model of vote choice, we establish two possible avenues by which they can lead to the different levels in AfD support we observed in the 2017 federal election. Either the voters in the two German regions differ systematically in their levels of populist and nativist sentiment, or these attitudes vary in salience (and therefore their input into the calculus of voting varies as well). The following section provides an 
overview of the data we used in our empirical analyses and sheds light on some important and innovative operationalisation strategies we employed.

\section{Data and Measures}

We analysed data from the German Longitudinal Election Study (GLES), specifically the online campaign panel survey (Roßteutscher et al. 2018) conducted in the context of the German federal election held on September 24, 2017. We drew on the first eight waves of the survey, which were fielded between October 2016 and October 2017. Of the 18,561 respondents originally recruited by Respondi or GapFish for the first wave, 10,599 respondents participated in wave 8, the first postelection wave. Because the recruitment process for the panel participants was based on a quota procedure, the realised sample is not representative of the German electorate. We therefore employed a weight designed to achieve representativeness by aligning the sample to data collected through the German Micro Census 2016. Despite this provision, concerns about representativeness remain and should be taken into account when interpreting the results, especially when distributions (as opposed to associations) are concerned.

The panel survey has several crucial advantages that outweigh concerns about representativeness. First, it includes detailed measures of the relevant concepts, namely voting decision, populism, and nativism. Furthermore, while the data on nativism and populism were collected before the election (in waves 1 and 5, respectively), the final electoral decisions were measured immediately after the election (in wave 8). This time-structure increases our confidence that the patterns reported below reflect causal relationships and not merely correlations. Third, the (initial) sample sizes of roughly 15,000 west German and 3000 east German respondents allows a more finegrained analysis than would be possible with smaller samples.

Turning to operationalisations, populism was measured using a variant of the scale developed by Schulz et al. (2018), which comprises three items to tap into different facets of each of the three subdimensions described above (i.e., anti-elitism attitudes, demand for sovereignty of the people, and a belief in the homogeneity of the people). Question wordings for these and all other items are reported in the appendix. As for nativism, the first subdimension (the degree to which citizens conceptualise the nation in ethnic terms) was measured with three items capturing the relevance of having German ancestors, having been born in Germany, and having lived one's whole life in Germany for being a "true German." This measurement approach follows a long research tradition concerned with measuring this particular type of national identity (e.g., Kunovich 2009). The second nativism dimension, xenophobia, was measured with items designed to capture the respondents' degree of anti-immigration sentiment, preference for assimilation of foreigners vis-à-vis multiculturalism, and tolerance of Islam in the German society. ${ }^{5}$ These issues are

\footnotetext{
5 Ideally, we would measure xenophobic attitudes with items that do not focus on specific groups of foreigners. Data restrictions unfortunately force us to rely on these available items. Measuring xenophobia
} 
generally considered to be core demands on radical-right parties' xenophobic agenda (Mudde 2007; Rydgren 2018).

Responses to the items measuring the subdimensions of populism and nativism, respectively, were aggregated by computing additive indexes. ${ }^{6}$ Reflecting the conceptual assumption that a high value in one subdimension does not compensate for low values in other subdimensions, we followed Wuttke et al. (2020) and computed populism and nativism scores by taking the minimum value a respondent had on any of the subdimensions measuring the respective concept. ${ }^{7}$ In the case of populism, this means that the populism score is the lowest score a person had on any of three populism subdimensions. Analogously, the aggregated nativism measure was derived based on the lowest value a person had indicated with respect to the items tapping into exclusionary attitudes and ethnonationalism. While this approach might lead to attenuated effect estimates, it reflects our understanding of populism and nativism as multidimensional constructs in which high values in one subdimension cannot simply offset lower values in another subdimension. This modelling strategy will be supplemented by the presentation of results referring to a separate evaluation of all subdimensions.

Vote choice in the postelection wave was measured with the standard GLES instrument, which asks respondents to indicate their electoral choice at the last federal election (see the online appendix for more detail). We used the answers to this question to create a dummy variable indicating a pro-AfD vote choice vis-à-vis a vote choice for any other party, reflecting the idea that a choice favouring one party is also a choice against all others. ${ }^{8}$ In our data set, $13 \%$ of the respondents (1054) who lived in western Germany and answered the vote-choice question indicated they had voted for the AfD, whereas in eastern Germany the percentage of AfD voters was $20 \%$ (332 respondents). The samples of respondents from both parts of the country are therefore large enough to allow multivariate analyses, and they correspond, in terms of the distribution of the dependent variable, quite closely with the actual election results, in which the AfD garnered $11 \%$ of the vote in western Germany and 22\% in the east (Der Bundeswahlleiter 2018).

We followed a specific research strategy in our attempt to explain not AfD support in its entirety but rather the contribution that populist and nativist idea elements make in explaining the observed difference in AfD support among east and west German voters. We therefore controlled only for standard sociodemographic variables (gender, age, education), political interest, urban versus rural place of residence, and personal economic situation. Detailed information about these measures can be found in the online appendix. To avoid an overspecification of our models by (wrongly) including mediating variables, we did not control for more proximate

\footnotetext{
using proxies like these is common but not ideal practice in the literature (e.g., Hjerm 1998, 2001; Jolly and DiGiusto 2014; Marfouk 2019). We revisit this issue in the conclusion.

${ }^{6}$ Factor analyses of each multidimensional concept yielded clean factor structures and acceptable model fits. Multigroup analyses showed cross-regional equivalence of the measures (Davidov et al. 2014). The details of this psychometric analysis are reported in the online appendix.

7 For a similar noncompensatory approach applied to antipartyism, see, for example, Rattinger (1993) and Maier (2000).

8 A supplementary analysis based on multinomial logistic regressions can be found in the online appendix.
} 
factors that might be related to nativist and populist idea elements as well as party preferences. Such variables could have been specific issue preferences (e.g, an asylum law reform) or candidate preferences (e.g., Merkel evaluation), or even party identification, as identifications with the AfD are unlikely to have crystallised given the youth and continuing evolution of the party, making it unclear what precisely a measure of identification with the AfD would truly mean. To avoid overspecification, we also refrained from controlling for phenomena that conceptually overlap with nativism and populism, such as some indicator of (absence of) system support in the case of the latter. ${ }^{9}$

\section{Results}

\subsection{East-West Differences in Distributions}

Are east Germans more populist and/or nativist than west Germans? To answer this question, we first looked at the relative frequency of populism, nativism, and their respective subdimensions in the two parts of the countries on average, as measured in the panel survey. In a second step we differentiated by age groups. Figure 1 shows that populist and nativist attitudes, operationalised as the minimum value on any of the three subdimensions per attitude, are indeed on average more frequent in the east. While $18 \%$ [95\% CI $=17,19]$ of the west German subsample exhibited scores of 4 or 5 on the populism measure, $26 \%[95 \% \mathrm{CI}=24,28]$ did so in the East German subsample. The corresponding percentages for nativism are $28 \%$ [95\% CI $=27,28]$ and $35 \%[95 \% \mathrm{CI}=33,36]$, respectively. ${ }^{10}$
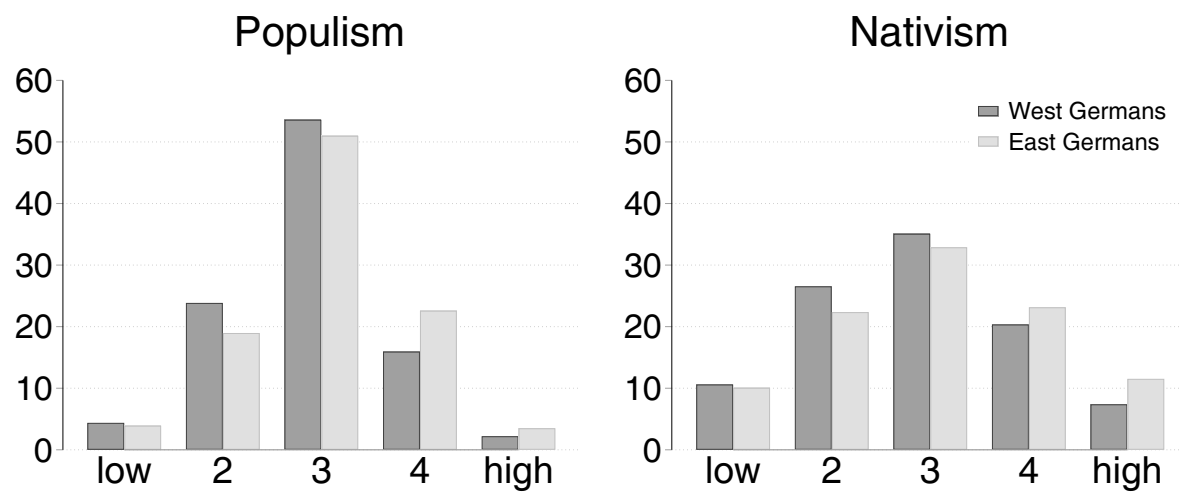

Fig. 1 Populism and nativism in east and west Germany

\footnotetext{
${ }^{9}$ In the interest of transparent research, we estimated additional models where party identification as well as alternative explanations for AfD voting (operationalised through Merkel evaluations, satisfaction with democracy, and external efficacy) are explicitly accounted for. These additional analyses can be found in the online appendix (section 5).

10 To improve the clarity of the descriptive analyses, all measures were collapsed to five-point scales. See the online appendix for details.
} 


\section{Populism}

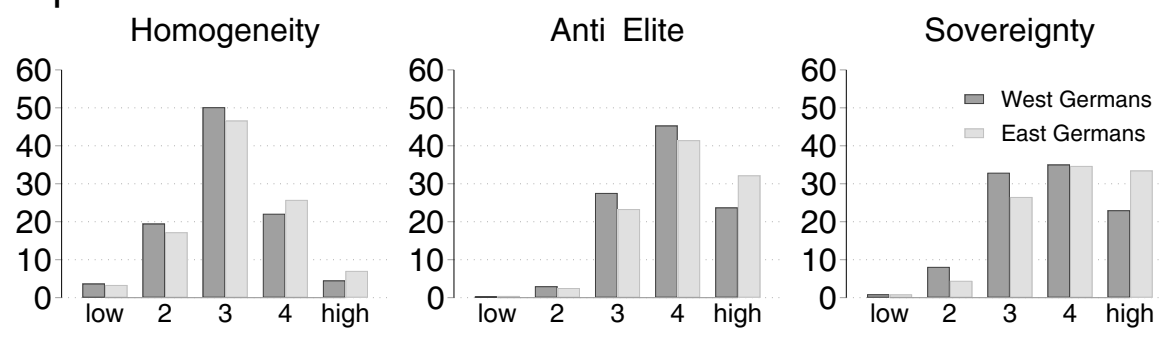

\section{Nativism}
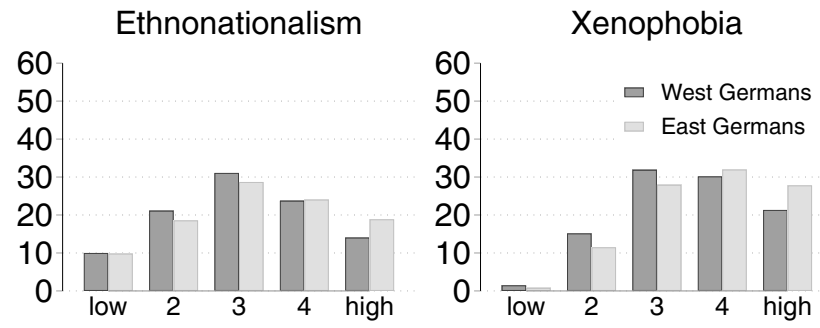

Fig. 2 Subdimensions of populism and nativism by region

Regarding whether the differences are driven by certain subdimensions of these multifaceted phenomena, Fig. 2 displays the distributions of subdimensions of populism and nativism in both parts of the country. The east-west differences are fairly consistent-we found slightly more elevated scores for east Germans in comparison to west Germans on all dimensions. The differences are particularly pronounced with regard to the idea of popular sovereignty, with $68 \%$ [95\% CI $=66,70]$ of east Germans exhibiting scores of 4 or 5 on this subdimension, as opposed to only $58 \%$ $[95 \% \mathrm{CI}=57,59]$ in west Germany. By and large, then, these statistics reveal differences in populism and nativism between west and east Germans that are consistent with the increased success of the AfD in the eastern part of the country.

To further explore these differences in populism and nativism, we compared east-west gaps among citizens who experienced their formative years when Germany was still divided and among younger citizens who did not. As noted above, people socialised in the GDR might be more populist and nativist than those socialised in the Federal Republic of Germany because their notion of democracy is less in line with the ideal of liberal representative democracy, they are less influenced by the civic notion of German national identity, and they are less accustomed to the idea of Germany as a multicultural society than their west German contemporaries.

Table 1 shows the percentages of respondents with high scores on populism and nativism and their respective subdimensions among younger and older east and west Germans. To create these age groups, we chose the age of 50 at the time of the first wave of the survey as the cut-off, meaning that those who were 19 years or older when the Berlin Wall fell constitute the "older" age category. The results show that the differences between older east Germans and the other three groups are 
Table 1 Populism and nativism in eastern and western Germany ${ }^{\mathrm{a}}$

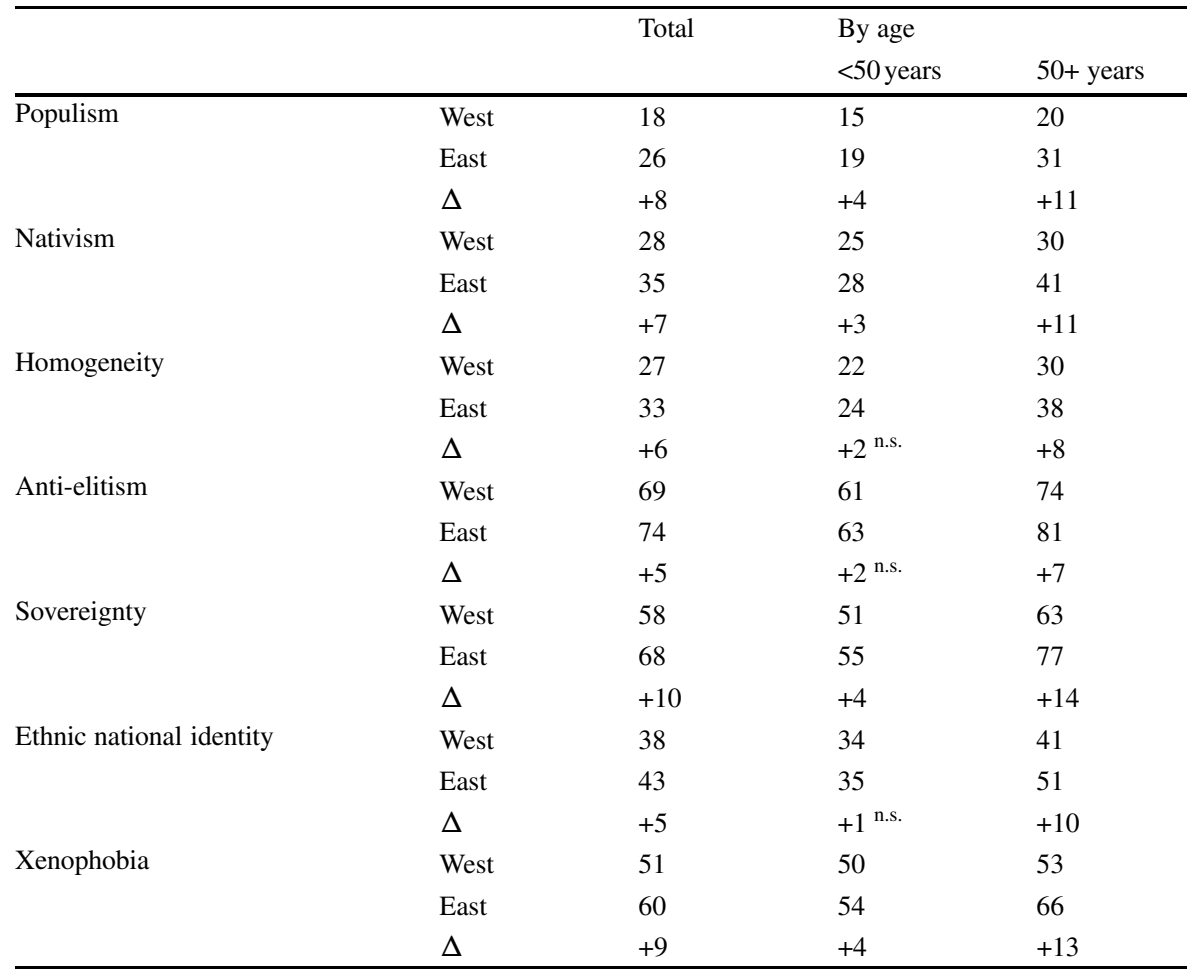

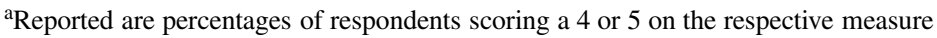
$n . s$. east-west differences that are not statistically significant $(p>0.05)$

particularly pronounced, with the former being consistently more populist and more nativist (overall and on the subdimensions) than the latter. ${ }^{11}$ According to these data, then, the real cleavage in the German populace in terms of populism and nativism levels is between older east Germans and the remaining population.

The distributions of the subdimensions, reported in the lower sections of Table 1, reproduce this picture. Differences between east and west German voters are driven by differences between the two cohorts who were politically socialised while the two German regions were separated.

Overall, the descriptive analysis of the first mechanism suggests the existence of higher levels of populism and nativism in eastern Germany, in particular among older east Germans. Nonetheless, our focus on east-west differences should not obscure the fact that there is also considerable overlap in the distributions between the two parts of the country. As Figs. 1 and 2 make abundantly clear, the overall distributions show more similarities than differences between the two German regions. To say

11 Consistently, regressing these attitudes on age group, region, and an interaction term between age group and region yields a statistically significant, positive coefficient for the interaction term in each instance (available from the authors upon request). 
that populism and nativism are more widespread in eastern Germany does not imply that there are no west Germans harbouring these ideas as well (they are almost as numerous as in the east), nor that there are no east Germans who reject them.

\subsection{East-West Differences in Effect Sizes}

Distributional differences represent only one mechanism explaining how the east-west gap in electoral support for the AfD could come about. To explore the relevance of the second mechanism, i.e., regional differences in populism and nativism effects on vote choice, we estimated logistic regressions of voting for the AfD on the two ideational orientations for east and west Germans separately, controlling for a range of basic individual characteristics that might influence ideational orientations and vote choice (but are unlikely to be influenced by nativism and populism). ${ }^{12}$ To explore the robustness of the effects, we first estimated regressions of voting for the AfD on populist attitudes alone (M1) and then on nativist attitudes

Table 2 Regression models of Alternative for Germany voting in eastern and western Germany ${ }^{\mathrm{a}}$

\begin{tabular}{lllllll}
\hline & M1: west & M1: east & M2: west & M2: east & M3: west & M3: east \\
\hline Populism & $2.05^{* * *}$ & $2.25^{* * *}$ & - & - & $0.99^{* * *}$ & $0.92^{*}$ \\
& $(0.23)$ & $(0.38)$ & & & $(0.25)$ & $(0.43)$ \\
Nativism & - & - & $3.54^{* * *}$ & $3.83^{* * *}$ & $3.36^{* * *}$ & $3.60^{* * *}$ \\
& & & $(0.19)$ & $(0.37)$ & $(0.19)$ & $(0.39)$ \\
Female & $-0.27^{* * *}$ & $-0.54^{* * *}$ & $-0.27^{* *}$ & $-0.66^{* * *}$ & $-0.27^{* *}$ & $-0.66^{* * *}$ \\
& $(0.08)$ & $(0.15)$ & $(0.08)$ & $(0.16)$ & $(0.08)$ & $(0.16)$ \\
Education: mid- & $-0.27^{* *}$ & 0.17 & -0.13 & 0.29 & -0.12 & 0.28 \\
dle & $(0.09)$ & $(0.25)$ & $(0.10)$ & $(0.26)$ & $(0.10)$ & $(0.26)$ \\
Education: high & $-0.51^{* * *}$ & -0.27 & $-0.24^{*}$ & 0.08 & -0.17 & 0.11 \\
& $(0.10)$ & $(0.27)$ & $(0.11)$ & $(0.28)$ & $(0.11)$ & $(0.29)$ \\
Age in years & $-0.01^{* * *}$ & -0.01 & $-0.01^{* * *}$ & -0.01 & $-0.01^{* * *}$ & $-0.01^{*}$ \\
& $(0.00)$ & $(0.00)$ & $(0.00)$ & $(0.01)$ & $(0.00)$ & $(0.01)$ \\
Political interest & $1.02^{* * *}$ & $0.94^{* *}$ & $1.15^{* * *}$ & $0.89^{* *}$ & $1.15^{* * *}$ & $0.91^{* *}$ \\
& $(0.18)$ & $(0.34)$ & $(0.18)$ & $(0.34)$ & $(0.18)$ & $(0.34)$ \\
Personal eco- & $-1.61^{* * *}$ & $-1.13^{* * *}$ & $-1.56^{* * *}$ & $-1.10^{* *}$ & $-1.55^{* * *}$ & $-1.06^{* *}$ \\
nomic situation & $(0.16)$ & $(0.33)$ & $(0.17)$ & $(0.34)$ & $(0.17)$ & $(0.34)$ \\
Rural environ- & -0.04 & -0.15 & -0.09 & -0.12 & -0.09 & -0.13 \\
ment & $(0.08)$ & $(0.14)$ & $(0.08)$ & $(0.15)$ & $(0.08)$ & $(0.15)$ \\
Constant & $-1.70^{* * *}$ & $-1.85^{* * *}$ & $-2.79^{* * *}$ & $-2.97^{* * *}$ & $-3.18^{* * *}$ & $-3.25^{* * *}$ \\
$N$ & $(0.24)$ & $(0.46)$ & $(0.25)$ & $(0.46)$ & $(0.26)$ & $(0.49)$ \\
& 7192 & 1500 & 7192 & 1500 & 7192 & 1500 \\
\hline
\end{tabular}

${ }^{\text {a}}$ Reported are logit coefficients with standard errors in parentheses ${ }^{*} p<0.05,{ }^{* *} p<0.01,{ }^{* * *} p<0.001$

12 Based on these criteria, we do not include party identification in these models. Identifications with the AfD are unlikely to have crystallised given the youth and continuing evolution of the party, and there is some evidence that partisan identities were generally in flux during and after the European refugee crisis (Mader and Schoen 2019). 


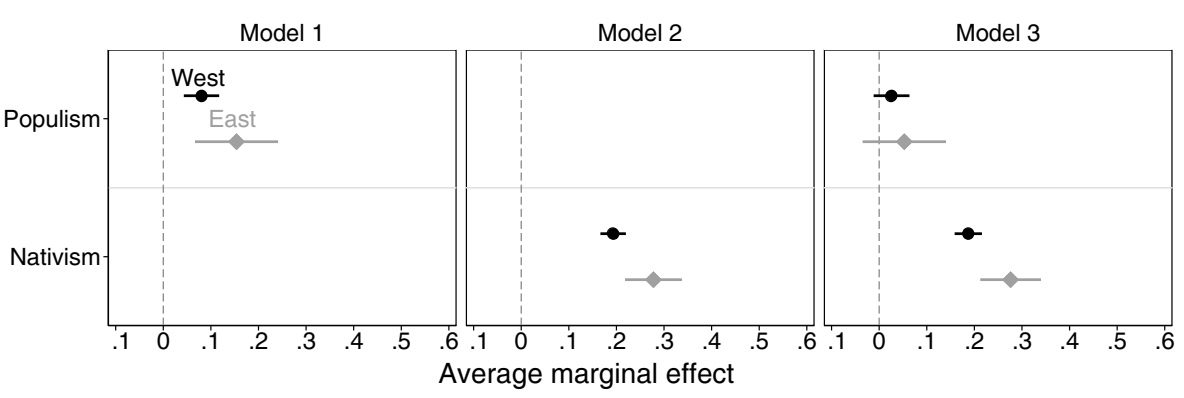

Fig. 3 Effects of populism and nativism on Alternative for Germany voting

alone (M2), followed by regressions containing both of our measures of interest in the same model (M3). ${ }^{13}$

The results from these logistic regressions are presented in Table 2. At first glance the findings are quite similar for eastern and western Germany. In both subgroups, the estimated logit coefficients for populism and nativism are positive and statistically significant. Logit coefficients and statistical significance are not helpful to ascertain (relative) effect sizes, which is why we computed average marginal effects of populist and nativist attitudes for the two regions and the three models (Fig. 3). The comparison of average marginal effects (AMEs) across regions and models shows that while both populism and nativism individually influence voting for the AfD, the effect size of populism more than halves with the addition of nativism in both subsamples, in the east from $0.34[95 \% \mathrm{CI}=0.23,0.44]$ to $0.12[95 \% \mathrm{CI}=0.01$, 0.23 ] and in the west from $0.22[95 \% \mathrm{CI}=0.17,0.27]$ to $0.10[95 \% \mathrm{CI}=0.05,0.15]$. In contrast, the effect sizes of nativism remain stable in the joint model for residents of both regions. Crucial for our interest in east-west differences is the consistently higher point estimate for nativism in the east compared to the west. In model 3, which controls for both of our ideational features of interest, this difference is substantial and-based on the criterion of overlap of confidence intervals-reliably detectable (AME east $=0.48[0.39 ; 0.56]$; west $=0.33[0.30 ; 0.37]$ ).

To complement our analysis of the second mechanism, in a next step we explored whether the combination of simultaneously holding populist and nativist views adds

Table 3 Probability of Alternative for Germany vote choice in subgroups

\begin{tabular}{lllll}
\hline & West & \multicolumn{3}{l}{ East } \\
$(\%)$ & & $(\%)$ & - \\
\hline Group 1: low populism, low nativism & 6 & - & 9 & +3 \\
Group 2: high populism, low nativism & 10 & +4 & 12 & +19 \\
Group 3: low populism, high nativism & 22 & +16 & 28 & +25 \\
Group 4: high populism, high nativism & 27 & +21 & 34 & \\
\hline
\end{tabular}

13 We also checked the robustness of the findings using multinomial regressions of the full set of votechoice options. This alternative of modelling the data yielded very similar estimates for the effects of interest. See the online appendix, section 4. 
additional motivation to voting for the AfD. To this end, we coded respondents into one of four groups, defined by different combinations of populism and nativism scores-a group with above-median scores on both populism or nativism scales, one with below-median scores on these scales, and two groups scoring high on only one of the scales, respectively. This variable indicating the type of ideational combination was then used to predict AfD vote using logistic regressions for eastern and western respondents.

Table 3 reports the resulting predicted probabilities of voting for the AfD among the four ideational types. ${ }^{14}$ The probability of choosing the AfD should be disproportionately high among voters scoring high on both populist and nativist attitudes. If the interaction was more pronounced in the east than the west, the nonadditivity should be more pronounced in the former than the latter subsample. The results, however, do not show evidence of nonadditive effects in eastern or western Germany. While voters in group 4 (high populism, high nativism) are most likely to vote for the AfD in both parts of the country, the difference in probability compared with citizens in group 1 (low populism, low nativism) is not disproportionately larger than the difference in probability between the other two groups and group 1, respectively.

As a way of summarising the findings, Fig. 4 displays the predicted probabilities of voting for the AfD among the four groups in eastern and western Germany in graphical form, adding confidence intervals and the respective subsample average of AfD voters. First, it once more shows that nativism was more relevant than populism for the AfD vote in the 2017 election. We would therefore have to conclude that "thick" nativism trumps "thin" populism in both German regions. At the same time, the predictions underscore that the ideational features we analysed are neither necessary nor sufficient to explain the AfD vote. Regarding the group with the lowest predicted probability, there are still $6 \%$ of AfD voters among west German citizens with relatively low populism and nativism scores. Their vote choice may

Group 1: low populism, low nativism

Group 2: high populism, low nativism

Group 3: low populism, high nativism

Group 4: high populism, high nativism

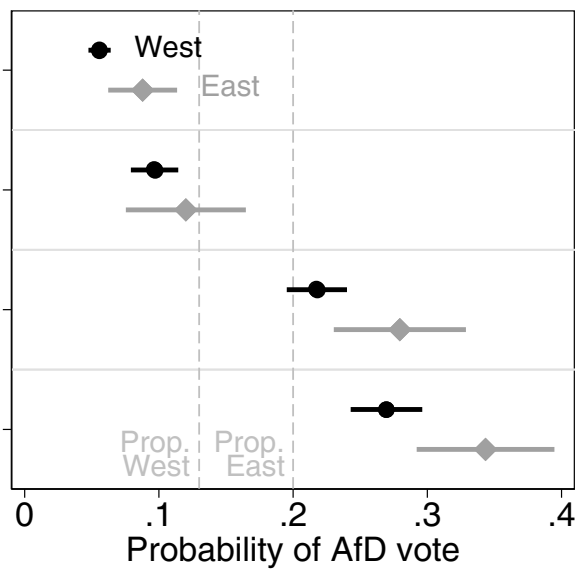

Fig. 4 Probability of Alternative for Germany voting in subgroups

${ }^{14}$ Regression results are presented in Table A2 in the online appendix. 
be explained by the other motives that extant research on radical-right voting has identified, such as economic considerations (Manow 2018; Rovny and Rovny 2017) and traditional protest voting and political alienation (e.g., Bieber et al. 2018). Regarding the group with the highest predicted probability, no more than $34 \%$ opted for the AfD among citizens with relatively high scores in eastern Germany. Put differently, two-thirds or more of those who are ideologically closely aligned with the AfD decided to vote for a different party. From this point of view, the findings attest to the ability of the other parties to win populists' and nativists' votes - at least in the 2017 election. $^{15}$

\section{Conclusion}

The AfD was significantly more successful at the polls in the eastern part of the country than in the west in the latest federal election. In this paper, we analysed the extent to which this difference can be traced back to nativist and populist attitudes. We considered two potential pathways, namely differences in the degree to which citizens in both parts of the country hold these attitudes and differences in the degree to which the attitudes enter into voting decisions. We also looked into the possibility that the weights of populist and nativist attitudes differed in such a way that in one region "thin" populism was more important than "thick" nativism, while in the other region the opposite relationship existed. The importance of answering this question transcends the quest for explaining regional electoral variation. Whenever questions regarding the definition and measurement of populist attitudes are concerned, an underlying issue is the fundamental question of whether populism can be regarded as an ideology at all (e.g., Aslanidis 2016), and whether Mudde's (2004) conception of populism as a thin ideology of limited scope is of use when attempting to understand populist movements, parties, and attitudes. If, as Mudde claims, the thin-centredness of populism lets it "be easily combined with [...] other ideologies" (2004, p. 544), what can we learn about its individual relevance once it has been combined with nativism?

Our results showed that east Germans, and older east Germans in particular, exhibited higher levels of both populism and nativism than (older) west Germans did. Furthermore, while both populism and nativism are relevant predictors of AfD choice in both parts of the country, east Germans (irrespective of their age) rely more heavily on their stance towards nativism than is the case for west Germans. No differences emerge for populism. These results are consistent with our reasons for focusing on populism and nativism as potential roots of the east-west divide in the first place.

\footnotetext{
15 To ascertain the robustness of the findings for the relative effect sizes, we (1) estimated multinomial regressions on the whole set of vote choices, not only on the binary distinction between voting for the AfD and not voting for the AfD, and (2) reran the analysis with party identity controls. In both instances the results were structurally the same as those presented here. Controlling for party identity attenuates effect sizes, however, resulting in an overlap of confidence intervals for the nativism effect. As argued above, this was to be expected, as the influence of nativism (and populism) is bound to flow in part through the development of an identification with the AfD—or at least to a corresponding response to the party identity item. For details, see the online appendix, sections 4 and 5.
} 
Both the differences in populism and nativism levels and differences in the effects of nativism are readily interpretable against the backdrop of different socialisation experiences with respect to representative democracy and national identity of the older generations in the two Germanys, lingering discrepancies in living conditions, and current differences in political discourse in the two parts of the country.

Beyond this partial illumination of the east-west difference, our study of the German federal election suggests that, in this case at least, populism came secondary to nativism in the calculus of the voters of the populist radical right. The findings reported above consistently point to larger effects of nativist attitudes than of populist attitudes in both parts of the country. We therefore must conclude that "thick" nativism is a better predictor of AfD voting than "thin" populism is, even though much of the public discourse concerns the populist appeal of the party. While it would be a stretch to claim that the same holds in other countries (and perhaps even in other German elections), these findings underscore that populism and the radical right should not be conflated, and researchers interested in the impact of populism should account for the second core dimension, nativism, characterising the (many) populist parties found within the right wing.

We would be remiss if we did not point out additional open questions and caveats. First, our measure of xenophobia, one of the two subdimensions of nativism, is not ideal. The responses to the items we used to construct this measure tap into attitudes towards selected specific aspects of foreignness in the German context and might not only be driven by xenophobia. For example, a preference for restrictive immigration, which is one of our four indicators of xenophobia, might in fact reflect economic interests and not a general dislike of foreigners and foreignness. As a result, the measured levels of xenophobia are likely inflated. Although we do not see an obvious reason why this imprecision should bias the estimates of east-west differences in nativism and its effect on vote choice, we cannot preclude that capturing variation at high levels of xenophobia might change the results and conclusions regarding these particular questions.

The descriptive statistics reported in the result section must be taken with a grain of salt because we analysed a sample of respondents from an online-access panel willing to go through repeated rounds of surveys over an extended period. This raises questions about the representativeness of the reported levels of populism and nativism. The fact that the relative frequency of AfD voters in the sample mirrors the real regional gap in AfD support quite closely bolsters our confidence in the data but cannot dispel the general problem. At the same time, note that these problems regarding the representativeness of the reported levels of populism and nativism do not touch directly on the main interest we have pursued in this paper, that is, the difference in these phenomena between the east and the west. The crucial question thus is whether the bias introduced by the nonprobability sample and panel attrition differs between east and west, thereby skewing the differences in populism and nativism scores we are most interested in. Although we do not see an obvious reason why such a systematic difference should occur, the descriptive analysis calls for suitable replications to bolster confidence in the conclusions.

On a more general level, the approach of analysing differences between "east" and "west" may be considered as slightly off target given the intraregional variation 
in both parts of the country. The AfD has western strongholds and eastern solitudes, so a more fine-grained analysis of regional variation is perhaps a better approach to understanding these differences, and surely a necessary addition (e.g., Evans et al. 2019). Such a fine-grained analysis might show that theoretically relevant variation-such as in socialisation experiences; in the salience of nativism, populism, and related issues; and on the supply side, especially in the appearance of the AfD_occurs at the communal or even neighbourhood level (Stecker and Debus 2019). In this context, we hasten to point out that the nature of this contribution was taxonomic rather than hypothesis-testing in a strict sense. We attempted to sketch two very general paths through which differences in populist and nativist orientations might translate into differences in AfD voting, without an explication of specifics or a systematic analysis of the boundary conditions identified as relevant in the theoretical model.

Against this backdrop, the present analysis constitutes one piece for solving the puzzle. Future research might complement our focus on ideational sources with an exploration of differences that stem from other prominent approaches to understanding the AfD vote in general, such as those focusing on economic considerations and the expression of discontent with a particular party. Such analyses should also pay close attention to the relationship between citizens' social situations, the material concerns that flow from them, and their ideational orientations. Our detached treatment of the ideational foundations of the AfD vote implicitly-and perhaps wrongly-assumes that these factors are relevant determinants of partisan preferences by themselves. Instead, they might be epiphenomena of more tangible considerations, such as material interests (Kalin and Sambanis 2018). Depending on the answers to this question, different implications follow for the present analysis. Most importantly, if citizens' stances towards populism and nativism are stable predispositions, the elevated levels of populism and nativism among east Germans imply that the east-west gap in AfD support is unlikely to change in the short term-at least if electoral supply remains the same and populism and nativism continues to be salient in German politics. At the same time, if the particularly high populist and nativist attitudes among older east Germans are indeed rooted in cohort effects, differences will phase out in the medium to long term.

Funding Open Access funding enabled and organized by Projekt DEAL.

Open Access This article is licensed under a Creative Commons Attribution 4.0 International License, which permits use, sharing, adaptation, distribution and reproduction in any medium or format, as long as you give appropriate credit to the original author(s) and the source, provide a link to the Creative Commons licence, and indicate if changes were made. The images or other third party material in this article are included in the article's Creative Commons licence, unless indicated otherwise in a credit line to the material. If material is not included in the article's Creative Commons licence and your intended use is not permitted by statutory regulation or exceeds the permitted use, you will need to obtain permission directly from the copyright holder. To view a copy of this licence, visit http://creativecommons.org/licenses/by/4. $0 /$. 


\section{References}

Akkerman, Agnes, Cas Mudde, and Andrej Zaslove. 2014. How Populist are the People? Measuring Populist Attitudes in Voters. Comparative Political Studies 47(9):1324-1353. https://doi.org/10.1177/ 0010414013512600 .

Arzheimer, Kai, and Elisabeth Carter. 2006. Political opportunity structures and right-wing extremist party success. European Journal of Political Research 45(3):419-443. https://doi.org/10.1111/j.1475-6765. 2006.00304.x.

Arzheimer, Kai, and Carl C. Berning. 2019. How the Alternative for Germany (AfD) and their voters veered to the radical right, 2013-2017. Electoral Studies 60(102040). https://doi.org/10.1016/j.electstud. 2019.04.004

Arzheimer, Kai, Harald Schoen, and Jürgen W. Falter. 2001. Rechtsextreme Orientierungen und Wahlverhalten. In Rechtsextremismus in der Bundesrepublik Deutschland: Eine Bilanz, edited by Wilfried Schubarth, and Richard Stöss, 220-45. Wiesbaden: VS Verlag für Sozialwissenschaften.

Arzheimer, Kai. 2021. Regionalvertretungswechsel von links nach rechts? Die Wahl von Alternative für Deutschland und Linkspartei in Ost-West-Perspektive. In Wahlen und Wähler - Analysen aus Anlass der Bundestagswahl 2017, ed. Bernhard Weßels, Harald Schoen. Wiesbaden: Springer. Forthcoming.

Aslanidis, Paris. 2016. Is Populism an Ideology? A Refutation and a new Perspective. Political Studies 64(1_suppl):88-104. https://doi.org/10.1111/1467-9248.12224.

Benček, David, and Julia Strasheim. 2016. Refugees welcome? A dataset on anti-refugee violence in Germany. Research \& Politics 3(4):205316801667959. https://doi.org/10.1177/2053168016679590.

Betz, Hans-Georg. 2017a. Nativism across time and space. Swiss Political Science Review 23(4):335-353. https://doi.org/10.1111/spsr.12260.

Betz, Hans-Georg. 2017b. Nativism and the success of populist mobilization. Revista Internacional de Pensamiento Politico 12:169-188.

Bieber, Ina, Sigrid Roßteutscher, and Philipp Scherer. 2018. Die Metamorphosen der AfD-Wählerschaft: Von einer euroskeptischen Protestpartei zu einer (r)echten Alternative? Politische Vierteljahresschrift 59(3):433-461. https://doi.org/10.1007/s11615-018-0103-y.

Blanchet, Alexandre, and Mike Medeiros. 2019. The secessionist spectre: the influence of authoritarianism, nativism and populism on support for Quebec independence. Nations and Nationalism 25(3):803-821. https://doi.org/10.1111/nana.12506.

Bowles, Harry. 2020. Comparing the Origins and Ideology of the UK Independence Party and Alternative für Deutschland: Is it Justified to include Respective Parties as Members of the 'Extreme Right' Party Family? The Elphinstone Review 6:48-62.

Campbell, Angus, Philip E Converse, Warren Edward Miller, Donald E Stokes. 1980. The American voter. Unabridged edition. Chicago: University of Chicago Press

Caramani, Daniele, and Luca Manucci. 2019. National past and populism: the re-elaboration of fascism and its impact on right-wing populism in Western Europe. West European Politics 42(6):1159-1187. https://doi.org/10.1080/01402382.2019.1596690.

Castanho Silva, Bruno, Ioannis Andreadis, Eva Anduiza, Nebojša Blanuša, Yazmin Morlet Corti, Gisela Delfino, et al. 2018. Public opinion surveys. In The ideational approach to populism. Concept, theory, and analysis, ed. Kirk Andrew Hawkins, Ryan E. Carlin, Levente Littvay, and Cristóbal Rovira Kaltwasser, 150-177. London, New York: Routledge.

Dalton, Russell J. 1994. Communists and Democrats: Democratic Attitudes in the Two Germanies. British Journal of Political Science 24(4):469-493. https://doi.org/10.1017/S0007123400006967.

Davidov, Eldad, Bart Meuleman, Jan Cieciuch, Peter Schmidt, and Jaak Billiet. 2014. Measurement Equivalence in Cross-National Research. Annual Review of Sociology 40(1):55-75. https://doi.org/10.1146/ annurev-soc-071913-043137.

Decker, Frank. 2016. The "Alternative for Germany:" Factors Behind its Emergence and Profile of a New Right-Wing Populist Party. German Politics and Society 34(2):1-16. https://doi.org/10.3167/gps. 2016.340201.

Decker, Frank. 2018. Was ist Rechtspopulismus? Politische Vierteljahresschrift 59(2):353-369. https://doi. org/10.1007/s11615-018-0062-3.

Der Bundeswahlleiter. 2018. Wahl zum 19. Deutschen Bundestag am 24. September 2017. Wiesbaden (Informationen des Bundeswahlleiters, Heft 5, Teil 2). https://www.bundeswahlleiter.de/dam/jcr/ a124b184-8fdb-4e2b-b519-b9f546d958c8/btw17_heft5-2.pdf. Accessed November 5th, 2020.

Dostal, Jörg Michael. 2015. The Pegida Movement and German Political Culture: Is Right-Wing Populism Here to Stay? The Political Quarterly 86(4):523-531. https://doi.org/10.1111/1467-923X.12204. 
Downs, Anthony. 1957. An Economic Theory of Political Action in a Democracy. Journal of Political Economy 65(2):135-150. https://doi.org/10.1086/257897.

Evans, Jocelyn, Paul Norma, Myles Gould, Nicholas Hood, Gilles Ivaldi, et al. 2019. Sub-national context and radical right support in Europe: policy brief. University of Nice-Sophia Antipolis. Nice. https:// halshs.archives-ouvertes.fr/halshs-02088993. Accessed 5 Feb 2019.

Goerres, Achim, Dennis C. Spies, and Staffan Kumlin. 2018. The Electoral Supporter Base of the Alternative for Germany. Swiss Political Science Review 24(3):246-269. https://doi.org/10.1111/spsr. 12306.

Hawkins, Kirk A., and Cristóbal Rovira Kaltwasser. 2017. What the (ideational) study of populism can teach us, and what it Can't. Swiss Political Science Review 23(4):526-542. https://doi.org/10.1111/ spsr. 12281.

Hawkins, Kirk A., Scott Riding, and Cas Mudde. 2012. Measuring populist attitudes. Edited by The committee on concepts and methods. Working Paper Series, 55. Mexico City: CIDE.

Hjerm, Mikael. 1998. National identities, national pride and xenophobia: a comparison of four western countries. Acta Sociologica 41(4):335-347.

Hjerm, Mikael. 2001. Education, xenophobia and nationalism: a comparative analysis. Journal of Ethnic and Migration Studies 27(1):37-60. https://doi.org/10.1080/13691830124482.

Jesse, Eckhard. 2017. AFD und die Linke - wieviel Populismus steckt in ihnen? Politische Studien 476:41-51.

Jolly, Seth K., and Gerald M. DiGiusto. 2014. Xenophobia and immigrant contact: French public attitudes toward immigration. The Social Science Journal 51(3):464-473. https://doi.org/10.1016/j. soscij.2013.09.018.

Kalin, Michael, and Nicholas Sambanis. 2018. How to think about social identity. Annual Review of Political Science 21(1):239-257. https://doi.org/10.1146/annurev-polisci-042016-024408.

Kešić, Josip, and Jan Willem Duyvendak. 2019. The nation under threat: secularist, racial and populist nativism in the Netherlands. Patterns of Prejudice 53(5):441-463. https://doi.org/10.1080/0031322X. 2019.1656886.

Klein, Markus, and Jürgen W. Falter. 1996. Die Wähler der Republikaner zwischen sozialer Benachteiligung, rechtem Bekenntnis und rationalem Protest. In Wahlen und politische Einstellungen in westlichen Demokratien, ed. Oscar W. Gabriel, Jürgen W. Falter, 149-173. Frankfurt am Main: Peter Lang.

Klein, Markus, Fabian Heckert, and Yannic Peper. 2018. Rechtspopulismus oder rechter Verdruss? Kölner Zeitschrift für Soziologie und Sozialpsychologie 70(3):391-417. https://doi.org/10.1007/s11577-0180564-4.

Kronenberg, Volker. 2013. Patriotismus in Deutschland. Perspektiven für eine weltoffene Nation, 3rd edn., Wiesbaden: VS.

Kunovich, Robert M. 2009. The sources and consequences of national identification. American Sociological Review 74(4):573-593. https://doi.org/10.1177/000312240907400404.

Mader, Matthias, and Harald Schoen. 2019. The European refugee crisis, party competition, and voters' responses in Germany. West European Politics 42(1):67-90. https://doi.org/10.1080/01402382.2018. 1490484.

Maier, Jürgen. 2000. Die zentralen Dimensionen der Politikverdrossenheit und ihre Bedeutung für die Erklärung von Nichtwahl und „Protestwahl“ in der Bundesrepublik Deutschland. In Die Republik auf dem Weg zur Normalität?, ed. Jan van Deth, Hans Rattinger, and Edeltraud Roller, 227-249. Wiesbaden: VS.

Manow, Philip. 2018. Die politische Ökonomie des Populismus. Berlin: Suhrkamp.

Marfouk, Abdeslam. 2019. I'm neither racist nor xenophobic, but: dissecting European attitudes towards a ban on Muslims' immigration. Ethnic and Racial Studies 42(10):1747-1765. https://doi.org/10. 1080/01419870.2018.1519585.

Martin, Christian W. 2019. Electoral participation and right wing authoritarian success-evidence from the 2017 federal elections in Germany. Politische Vierteljahresschrift 60(2):245-271. https://doi.org/ 10.1007/s11615-018-00148-4.

Mudde, Cas. 2004. The Populist Zeitgeist. Government \& Opposition 39(4):542-563. https://doi.org/10. 1111/j.1477-7053.2004.00135.x.

Mudde, Cas. 2007. Populist radical right parties in Europe. Cambridge: Cambridge University Press. https://doi.org/10.1017/CBO9780511492037.

Mudde, Cas, and Cristóbal Rovira Kaltwasser. 2017. Populism. A very short introduction. Oxford, New York: Oxford University Press. 
Olsen, Jonathan. 2018. The left party and the AfD. German Politics and Society 36(1):70-83. https://doi. org/10.3167/gps.2018.360104.

Otjes, Simon, Gilles Ivaldi, Anders Ravik Jupskås, and Oscar Mazzoleni. 2018. It’s not economic interventionism, stupid! Reassessing the political economy of radical right-wing populist parties. Swiss Political Science Review 24(3):270-290. https://doi.org/10.1111/spsr.12302.

Pappi, Franz Urban, Anna-Sophie Kurella, and Thomas Bräuninger. 2019. Die Etablierung neuer Parlamentsparteien. Wählerpräferenzen als Erfolgsfaktor für die Alternative für Deutschland 2017 und die Grünen 1986. Politische Vierteljahresschrift 60(2):273-298. https://doi.org/10.1007/s11615-01900150-4.

Pickel, Gert. 2019. Weltanschauliche Vielfalt und Demokratie. Gütersloh: Bertelsmann Stiftung.

Poutrus, Patrice G., Jan C. Behrends, and Dennis Kuck. 2000. Historische Ursachen der Fremdenfeindlichkeit in den neuen Bundesländern. Aus Politik und Zeitgeschichte 39(B):15-21.

Rabinowitz, George, and Stuart Elaine Macdonald. 1989. A directional theory of issue voting. The American Political Science Review 83(1):93-121. https://doi.org/10.2307/1956436.

Rattinger, Hans. 1993. Abkehr von den Parteien? Dimensionen der Parteiverdrossenheit. Aus Politik und Zeitgeschichte https://doi.org/10.20378/IRBO-52949.

Riedel, Rafal. 2018. Nativism versus nationalism and populism-bridging the gap. Central European Papers 6(2):18-28.

Rooduijn, Matthijs. 2014. Vox populismus: a populist radical right attitude among the public? Nations and Nationalism 20(1):80-92. https://doi.org/10.1111/nana.12054.

Rooduijn, Matthijs, and Tjitske Akkerman. 2017. Flank attacks. Party Politics 23(3):193-204. https://doi. org/10.1177/1354068815596514.

Roßteutscher, Sigrid, Rüdiger Schmitt-Beck, Harald Schoen, Bernhard Weßels, Christof Wolf, Maria Preißinger, et al. 2018. Wahlkampf-Panel 2017 (GLES). With assistance of University of Mannheim, Chair for Political Psychology.

Rovny, Allison E., and Jan Rovny. 2017. Outsiders at the ballot box: operationalizations and political consequences of the insider-outsider dualism. Socio-Economic Review 41:mww39. https://doi.org/ 10.1093/ser/mww039.

Rydgren, Jens. 2018. The radical right: an introduction. In The Oxford handbook of the radical right, ed. Jens Rydgren, 1-16. New York: Oxford University Press.

Schmitt-Beck, Rüdiger, Jan W. van Deth, and Alexander Staudt. 2017. Die AfD nach der rechtspopulistischen Wende. Z Politikwiss 27(3):273-303. https://doi.org/10.1007/s41358-017-0104-1.

Schubarth, Wilfried, and Thomas Schmidt. 1992. „Sieger der Geschichte“. Verordneter Antifaschismus und die Folgen. In Der Antifaschistische Staat entlässt seine Kinder. Jugend und Rechtsextremismus in Ostdeutschland, ed. Karl-Heinz Heinemann, and Wilfried Schubarth, 12-28. Köln: PapyRossa.

Schulz, Anne, Philipp Müller, Christian Schemer, Dominique Stefanie Wirz, Martin Wettstein, and Werner Wirth. 2018. Measuring populist attitudes on three dimensions. International Journal of Public Opinion Research 30(2):316-326. https://doi.org/10.1093/ijpor/edw037.

Schwarzbözl, Tobias, and Matthias Fatke. 2016. Außer Protesten nichts gewesen? Das politische Potenzial der AfD. Politische Vierteljahresschrift 57(2):276-299. https://doi.org/10.5771/0032-3470-2016-2276.

Searing, Donald, Gerald Wright, and George Rabinowitz. 1976. The primacy principle: attitude change and political socialization. British Journal of Political Science 6(1):83-113. https://doi.org/10.1017/ S0007123400000533.

Sears, David O., and Christina Brown. 2013. Childhood and adult political development. In The Oxford handbook of political psychology, 2nd edn., ed. Leonie Huddy, David O. Sears, and Jack S. Levy, 59-95. Oxford: Oxford University Press.

Statistische Ämter des Bundes und der Länder (ed.). 2015. 25 Jahre Deutsche Einheit. Wiesbaden: Statistische Ämter des Bundes und der Länder.

Statistisches Bundesamt. 2018. Migration und Integration. Ausländische Bevölkerung nach Bundesländern. https://www.destatis.de/DE/Themen/Gesellschaft-Umwelt/Bevoelkerung/Migration-Integra tion/Tabellen/auslaendische-bevoelkerung-bundeslaender.html. Accessed 29 Aug 2019.

Stecker, Christian, and Marc Debus. 2019. Refugees Welcome? Zum Einfluss der Flüchtlingsunterbringung auf den Wahlerfolg der AfD bei der Bundestagswahl 2017 in Bayern. Politische Vierteljahresschrift 60(2):299-323. https://doi.org/10.1007/s11615-019-00151-3.

Steiner, Nils D., and Claudia Landwehr. 2018. Populistische Demokratiekonzeptionen und die Wahl der AfD: Evidenz aus einer Panelstudie. Politische Vierteljahresschrift 59(3):463-491. https://doi.org/10. 1007/s11615-018-0083-y. 
Träger, Hendrik. 2017. Die Parteien und die Repräsentation der Ostdeutschen. In Parteien und soziale Ungleichheit, ed. Elmar Wiesendahl, 331-357. Wiesbaden: Springer VS.

Wagner, Ulrich, Rolf van Dick, Thomas F. Pettigrew, and Oliver Christ. 2003. Ethnic prejudice in east and west Germany: the explanatory power of intergroup contact. Group Processes \& Intergroup Relations 6(1):22-36. https://doi.org/10.1177/1368430203006001010.

Wuttke, Alexander, Christian Schimpf, and Harald Schoen. 2020. When the whole is greater than the sum of its parts: on the conceptualization and measurement of populist attitudes and other multidimensional constructs. American Political Science Review 47:1-19.https://doi.org/10.1017/ S0003055419000807. 